\title{
Antibacterial mechanisms of a novel type picosecond laser-generated silver-titanium nanoparticles and their toxicity to human cells
}

This article was published in the following Dove Press journal: International Journal of Nanomedicine

\author{
Peri Korshed \\ Lin $\mathrm{Li}^{2}$ \\ Zhu Liu ${ }^{3}$ \\ Aleksandr Mironov ${ }^{4}$ \\ Tao Wang'
}

'School of Biological Science, Faculty of Biology, Medicine and Health, ${ }^{2}$ Laser Processing Research Centre, School of Mechanical, Aerospace and Civil Engineering, ${ }^{3} \mathrm{School}$ of Materials, ${ }^{4}$ Core Research Facilities, Faculty of Biology, Medicine and Health, The University of Manchester, Manchester, UK
Correspondence: Tao Wang School of Biological Science, Faculty of Biology, Medicine and Health, The University of Manchester, AV Hill Building I.014, Oxford Road, Manchester MI3 9PL, UK

Tel +44 I6I 275 I508

$\mathrm{Fax}+44$ I6I 2753938

Email tao.wang@manchester.ac.uk

Lin $\mathrm{Li}$

Laser Processing Research Centre, School of Mechanical, Aerospace and Civil Engineering, The University of Manchester, Manchester MI3 9PL, UK

Tel +44 I6I 3063816

Fax +44 I6I 3063803

Email lin.li@manchester.ac.uk
Abstract: In this study, we explored the antibacterial mechanisms for a novel type of $\mathrm{Ag}-\mathrm{TiO}_{2}$ compound nanoparticles (NPs) produced from an $\mathrm{Ag}-\mathrm{TiO}_{2}$ alloy using a picosecond laser and evaluated the toxicity of the $\mathrm{Ag}-\mathrm{TiO}_{2} \mathrm{NPs}$ to a range of human cell types. Transmission electron microscopy was used to determine the morphology, shapes, and size distribution of the laser-generated $\mathrm{Ag}-\mathrm{TiO}_{2} \mathrm{NPs}$. UV-visible spectrometer was used to confirm the shift of light absorbance of the NPs toward visible light wavelength. Results showed that the lasergenerated $\mathrm{Ag}-\mathrm{TiO}_{2} \mathrm{NPs}$ had significant antibacterial activities against both Gram-negative and Gram-positive bacterial strains, including Escherichia coli, Pseudomonas aeruginosa, and the methicillin-resistant Staphylococcus aureus. Increased level of reactive oxygen species was produced by $E$. coli after exposure to the $\mathrm{Ag}-\mathrm{TiO}_{2} \mathrm{NPs}$, which was accompanied with lipid peroxidation, glutathione depletion, disintegration of cell membrane and protein leakage, leading to the cell death. Five types of human cells originated from lung (A549), liver (HePG2), kidney (HEK293), endothelium cells (human coronary artery endothelial cells [hCAECs]), and skin (human dermal fibroblast cells $[\mathrm{HDFc}]$ ) were used to evaluate the cytotoxicity of the lasergenerated $\mathrm{Ag}-\mathrm{TiO}_{2} \mathrm{NPs}$. A weak but statistically significant decrease in cell proliferation was observed for hCAECs, A549 and HDFc cells when co-cultured with $2.5 \mu \mathrm{g} / \mathrm{mL}$ or $20 \mu \mathrm{g} / \mathrm{mL}$ of the laser-generated $\mathrm{Ag}-\mathrm{TiO}_{2} \mathrm{NPs}$ for 48 hours. However, this effect was no longer apparent when a higher concentration of NPs $(20 \mu \mathrm{g} / \mathrm{mL})$ was used after 72 hours of co-culture with human cells, suggesting a possible adaptive process in the cells had occurred. We conclude that picosecond laser-generated $\mathrm{Ag}-\mathrm{TiO}_{2} \mathrm{NPs}$ have a broad spectrum of antibacterial effect, including against the drug-resistant strain, with multiple underlying molecular mechanisms and low human cell toxicity. The antimicrobial properties of the new type of picoseconds laser-generated Ag- $\mathrm{TiO}_{2}$ compound NPs could have potential biomedical applications.

Keywords: silver-titanium nanoparticles, bactericidal, picoseconds laser, reactive oxygen species, cytotoxicity, compound nanoparticles, methicillin-resistant Staphylococcus aureus

\section{Introduction}

Silver nanoparticles (Ag NPs) and titanium oxide nanoparticles ( $\left.\mathrm{TiO}_{2} \mathrm{NPs}\right)$ are the two types of nanoparticles (NPs) that are most widely used as antimicrobial agents. Silver was historically known to have antibacterial properties and has been used against a wide range of bacteria, fungi and viruses. ${ }^{1}$ The applications of Ag NPs include, but not limited to, water purification, disinfection of medical devices, treating burns and wounds. ${ }^{2-4}$ However, Ag NPs are prone to oxidation that results in loss of antibacterial properties. Ag NPs can also be expensive if large amounts are required. On the other hand, $\mathrm{TiO}_{2}$ NPs are more stable and cheaper than Ag NPs, but their activation requires submit your manuscript Dovepress $f y$ in 1 http://dx,doi.org 10.21471 IN S1 40222 cC) and incorporate the Creative Commons Attribution - Non Commercial (unported, v3.0) License (http://creativecommons.org/licenses/by-nc/3.0/). By accessing the work you hereby accept the Terms. Non-commercial uses of the work are permitted without any further permission from Dove Medical Press Limited, provided the work is properly attributed. For permission for commercial use of this work, please see paragraphs 4.2 and 5 of our Terms (https://www.dovepress.com/terms.php). 
ultraviolet (UV) light illumination to initiate a photocatalyst process, which limits their applications. ${ }^{5}$ To maximize the application potential of both Ag NPs and $\mathrm{TiO}_{2}$ NPs, composite $\mathrm{Ag}$ and $\mathrm{TiO}_{2}$ NPs were produced in recent years. ${ }^{6,7}$ Combinations of Ag NPs with $\mathrm{TiO}_{2}$ NPs could enhance the photocatalytic property of $\mathrm{TiO}_{2}$ by promoting electron-hole separation and introducing more surface area absorption. ${ }^{8}$ Adsorption of visible light by Ag NPs surface could also stimulates electron transfer to $\mathrm{TiO}_{2} \mathrm{NPs}$, resulting in charge separation and activation of $\mathrm{TiO}_{2}$ NPs by visible light. ${ }^{9}$

The molecular and cellular mechanisms that underline the antibacterial properties of either Ag NPs or $\mathrm{TiO}_{2} \mathrm{NPs}_{\mathrm{N}}$ separately have been studied extensively. ${ }^{10,11}$ Under UV light, the electron-holes in $\mathrm{TiO}_{2}$ NPs interact with water and oxygen to generate reactive oxygen species (ROS), especially hydroxyl radicals, ${ }^{12}$ achieving antibacterial effects. Multiple mechanisms, including ROS generation contribute to the bactericidal effect of Ag NPs. ${ }^{10}$ However, the molecular mechanisms by which the composite $\mathrm{Ag}-\mathrm{TiO}_{2} \mathrm{NPs}_{\mathrm{N}}$ kill bacteria have been largely underinvestigated. In addition, the toxicity of the Ag$\mathrm{TiO}_{2}$ composite NPs to human cells are awaiting to be fully characterized. It is known that $\mathrm{TiO}_{2}$ is relatively safe ${ }^{13}$ and has been approved by the US Food and Drug Administration (FDA) to be used as a colorant in food, drugs and cosmetics, including sunscreens. ${ }^{14}$ The toxic effect of Ag NPs on human cells, however, is a subject of debate. ${ }^{15,16}$ It is believed that the cytotoxicity of Ag NPs to humans is generally low, but numerous reports did show side effects of Ag NPs. For example, long time skin exposure to Ag NPs could turn the skin into blush gray called argyria. ${ }^{17}$ Structure changes in human liver cells were observed when exposing to Ag NPs. ${ }^{17}$ The toxic effect of Ag NPs could potentially be reduced when combined with $\mathrm{TiO}_{2}$ NPs through reducing the amount of $\mathrm{Ag}$ NPs used, but there is hardly any information documenting the cytotoxicity of the composite $\mathrm{Ag}-\mathrm{TiO}_{2} \mathrm{NPs}$.

Composite $\mathrm{Ag}$ and $\mathrm{TiO}_{2}$ NPs can be produced in different ways. Majority of them were generated by chemical, ${ }^{18}$ sonochemical ${ }^{19}$ or sol-gel based methods. ${ }^{20}$ Juan et al deposited Ag NPs on titanium surface by salinization. Their results showed that the composite $\mathrm{Ag}-\mathrm{TiO}_{2}$ surface could kill 94\% of Staphylococcus aureus and 95\% of Escherichia coli after 24 hours incubation. ${ }^{4}$ Using a chemically based method, Pan et al synthesized $\mathrm{Ag}$ and $\mathrm{TiO}_{2}$ nanocomposite, which could completely inhibit $E$. coli survival under visible light irradiation and the antibacterial activity was 5 folds higher than that of $\mathrm{TiO}_{2}$ alone. ${ }^{21}$ Ag-doped $\mathrm{TiO}_{2}$ NPs were synthesized, which showed antibacterial effects against 3 bacterial strains, E. coli, Pseudomonas aeruginosa and S. aureus under visible light irradiation and the antibacterial activity of the Ag-doped $\mathrm{TiO}_{2}$ NPs was superior to $\mathrm{TiO}_{2}$ NPs alone. ${ }^{6}$ However, NPs generated by these methods inevitably carry chemical contaminants. Additional cleaning steps are usually required to purify the NPs, which would complicate the application process.

Recently, we have applied laser technology to the production of NPs. ${ }^{10,22}$ The process is carried out in pure water, free of any chemical contaminations. Composite NPs can be rapidly generated by simultaneous ablation of bulk metal blocks in the same reaction using a laser beam. The physical properties of NPs can also be controlled by applying various laser processing parameters. ${ }^{23}$ Therefore, the laser-generated NPs have great potential for biomedical applications. Using picosecond laser ablation, we have recently produced Agdoped $\mathrm{TiO}_{2}$ NPs from a Ti/Ag bulk alloy for the first time. ${ }^{22}$ The Ag- $\mathrm{TiO}_{2}$ compound NPs significantly shifted the $\mathrm{TiO}_{2}$ optical absorption spectra to longer visible light wavelength $(\sim 500 \mathrm{~nm})$, and initial experiment demonstrated their antibacterial effect against $E$. coli under day light.22

In the present study, we conducted a comprehensive characterization on the antibacterial activities of this novel type

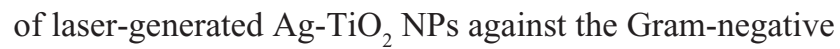
bacteria $E$. coli and $P$. aeruginosa, and the Gram-positive and methicillin-resistant $S$. aureus (MRSA) under day light condition, explored the molecular mechanisms underlying the antibacterial effects, and evaluated toxicity against 5 types of human cells. We found that the picosecond lasergenerated $\mathrm{Ag}-\mathrm{TiO}_{2}$ compound NPs had a broad spectrum of antibacterial effect, including the drug-resistant strain MRSA with low human cell toxicity. Multiple mechanisms, including increased cellular ROS generation, lipid peroxidation (LPO), glutathione (GSH) depletion, disintegration of cell membrane and protein leakage contributed to the bactericidal effects of the laser-generated compound $\mathrm{Ag}-\mathrm{TiO}_{2} \mathrm{NPs}_{\text {. }}$

\section{Materials and methods NP production}

NPs were produced by pulsed laser ablation of bulk metal blocks in an aqueous phase (deionized water) as described in our previous publications. ${ }^{22} \mathrm{Ag}-\mathrm{TiO}_{2} \mathrm{NPs}$ were generated by laser ablation of $\mathrm{Ag} / \mathrm{Ti}$ alloy. For a comparative study, $\mathrm{TiO}_{2}$ NPs and Ag NPs were generated by laser ablation of Ti plate and Ag plate, respectively. Briefly, the Ag/Ti alloy plate, Ti plate and Ag plate were washed with ethanol and sterile deionized water to remove any organic compounds on the target surfaces. The metal plates were then placed at the bottom of a $70 \mathrm{~mL}$ glass vessel that contained $20 \mathrm{~mL}$ 
of $\mathrm{dH}_{2} \mathrm{O}$. An Edgewave (Würselen, Germany) picosecond laser was used to produce the NPs with the following parameters: wavelength $\lambda=1,064 \mathrm{~nm}$, frequency $f=200 \mathrm{kHz}$, laser power $P=9.12 \mathrm{w}$, pulse width $t=10 \mathrm{ps}$, spot size $D=125 \mu \mathrm{m}$, scan speed $v=250 \mathrm{~mm} \mathrm{~s}^{-1}$, laser pulse energy $E_{\text {pulse }}=45.6 \mu \mathrm{J}$ and laser fluence $F_{\text {laser }}=0.3717 \mathrm{~J} / \mathrm{cm}^{2}$.

\section{UV-visible spectrophotometry}

The absorption spectrum of different concentrations of lasergenerated $\mathrm{TiO}_{2}$ and $\mathrm{Ag}-\mathrm{TiO}_{2}$ NPs was measured by Synergy HTX Multi-Mode Reader (BioTek, Swindon, UK). Quartz cuvette was used and triplicate samples were measured at each laser $\mathrm{Ag}$ and $\mathrm{Ag}-\mathrm{TiO}_{2} \mathrm{NP}$ concentration. The absorbance curve was made by plotting the wavelength $(100-700 \mathrm{~nm})$ versus the absorbance.

\section{Bacteria culture and the determination of antibacterial activities of NPs}

Single colonies of the Gram-negative bacteria, E. coli (JM109, Promega, Southampton, UK) or P. aeruginosa (ATCC, 9,027) ${ }^{24}$, or the Gram-positive bacteria, S. aureus (ATCC, 43,300 methicillin-resistant strain $)^{25}$ were inoculated, in $10 \mathrm{~mL}$ of autoclaved Muller-Hinton broth media (Sigma-Aldrich, Dorset, UK), respectively, and then incubated at $37^{\circ} \mathrm{C}$ overnight with shaking at $225 \mathrm{rpm}$. The culture of bacteria suspension was diluted to give $10^{4} \mathrm{cfu} / \mathrm{mL}$ ready to be used for the antibacterial experiments below. The antibacterial activity of NPs was determined following the standard Nathan's agar well-diffusion technique. Briefly, the bacterial culture prepared above was spread uniformly on the MullerHinton agar plates using sterile cotton swabs and left for 10 minutes for absorption. Then $6 \mathrm{~mm}$ wells were made by punching the Muller-Hinton agar plates with a cylinder glass tube. NP sample solution $50 \mu \mathrm{L}$ at different concentrations was added into each well and was incubated at $37^{\circ} \mathrm{C}$ for 18 hours. The zones of inhibition (ZOIs) which reflect the susceptibility of microbes to the NPs were then measured ${ }^{10}$ and presented as the average value from 2-4 measurements for each well.

\section{Detection of ROS generation}

ROS detection reagents, 2,7-dichlorofluorescein diacetate (DCFH-DA, Sigma-Aldrich), was used in the study. First of all, E. coli bacterial cells in a density of $10^{4} \mathrm{cfu} / \mathrm{mL}$ were incubated with laser-generated $\mathrm{Ag}-\mathrm{TiO}_{2} \mathrm{NPs}$ at different concentrations $(10,30$ and $50 \mu \mathrm{g} / \mathrm{mL})$ for 5 hours at $37^{\circ} \mathrm{C}$ in triplicate with shaking at $225 \mathrm{rpm}$. The bacterial cells were then pelleted by centrifugation at $1,000 \mathrm{rpm}$ for 5-10 minutes.
The bacterial cell pellet was suspended in $1 \mathrm{~mL} \mathrm{LB}$ broth. DCFH-DA reagent was added to the cell suspension to give a final concentration of $100 \mu \mathrm{M}$ followed by incubation at $37^{\circ} \mathrm{C}$ for 30 minutes in dark. Cell suspension $200 \mu \mathrm{L}$ was transferred to a well of a 96-well plate in triplicate. The fluorescence was measured by a spectrophotometer (LUMIstar ${ }^{\circledR}$ Omega, BMG LABTECH GmbH, Ortenberg, Germany) at an excitation wavelength $485 \mathrm{~nm}$ and emission wavelength $528 \mathrm{~nm} .{ }^{26}$

\section{GSH reductase measurement}

E. coli of $10^{4} \mathrm{cfu} / \mathrm{mL}$ was incubated with $15 \mu \mathrm{g} / \mathrm{mL}$ lasergenerated $\mathrm{Ag}-\mathrm{TiO}_{2} \mathrm{NPs}$ in the shaker for 3-5 hours. $\mathrm{H}_{2} \mathrm{O}_{2}$ ( $4 \mu \mathrm{g} / \mathrm{mL}$ ) was used as positive control, and equal volume of $\mathrm{dH}_{2} \mathrm{O}$ was used as negative (NP-free) control. Following the treatment of $E$. coli by $\mathrm{Ag}-\mathrm{TiO}_{2} \mathrm{NPs}$, GSH reductase level was measured according to the manufacturer's instruction. Bacterial samples $100 \mu \mathrm{L}$ treated with $\mathrm{Ag}_{-} \mathrm{TiO}_{2}$ NPs or the controls were mixed with $500 \mu \mathrm{L}$ oxidized GSH, $100 \mu \mathrm{L}$ assay buffer, $250 \mu \mathrm{L}$ of 5,5'-Dithiobis(2-nitrobenzoic acid), and $50 \mu \mathrm{L}$ nicotinamide adenine dinucleotide phosphate. Each reaction $200 \mu \mathrm{L}$ was transferred to a well of 96-well plate and read by the Spectrophotometer (Omega) at $450 \mathrm{~nm}$.

\section{LPO analysis}

LPO malondialdehyde (MDA) assay kit (Cat No MAK085/ Sigma-Aldrich) was used to determine MDA that is a byproduct of LPO of bacterial cell membrane. Briefly, bacterial culture $\left(10^{4} \mathrm{cfu} / \mathrm{mL}\right)$ was treated with laser-generated $\mathrm{Ag}-\mathrm{TiO}_{2}$ NPs in final concentrations of $5,10,15$ and $20 \mu \mathrm{g} / \mathrm{mL}$ by incubating at $37^{\circ} \mathrm{C}$ with shaking for 3 hours. Bacterial suspension $1 \mathrm{~mL}$ was homogenized in ice with $300 \mu \mathrm{L}$ MDA lysis buffer and $3 \mu \mathrm{L}$ of butylated hydroxytoluene and then centrifuged at $13,000 \times g$ for 10 minutes to remove insoluble materials. Then $200 \mu \mathrm{L}$ of the supernatant from each homogenized sample was placed into a microcentrifuge tube and $600 \mu \mathrm{L}$ of the thiobarbituric acid (TBA) solution was added into each tube. The reaction was incubated at $95^{\circ} \mathrm{C}$ for 60 minutes in order for the MDA and TBA to form complex, and then cooled down by placing the tubes into ice bath for 10 minutes. Finally, $200 \mu \mathrm{L}$ of the reaction from each tube was transferred into a well of 96-well plates for absorbance measurement at a wavelength of $532 \mathrm{~nm}$.

\section{Lactate dehydrogenase $(\mathrm{LDH})$ release assay}

E. coli at $10^{4} \mathrm{cfu} / \mathrm{mL}$ were cultured in $96-$ well plates in $200 \mu \mathrm{L}$ Muller-Hinton media in triplicate at $37^{\circ} \mathrm{C}$ overnight. The cells were then treated with $10 \mu \mathrm{L}$ laser $\mathrm{Ag}-\mathrm{TiO}_{2}$ 


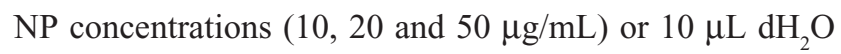
as control and further incubated at $37^{\circ} \mathrm{C}$ overnight. Lysis buffer $10 \mu \mathrm{L}$ from the LDH assay kit (Fisher Scientific, Loughborough, UK/Cat No 88954) was then added and mixed by gently tapping and incubated at $37^{\circ} \mathrm{C}$ for 45 minutes. Cell lysate $50 \mu \mathrm{L}$ from each sample was then transferred to a new $96-$ well plate and $50 \mu \mathrm{L}$ reaction buffer from the kit was added to each well and mixed gently. The plate was then left at room temperature for 30 minutes in dark before $50 \mu \mathrm{L}$ stop solution was added to each well and mixed by gentle tapping. Finally, OD absorbance was measured at $490 \mathrm{~nm}$ using the spectrophotometer (Omega).

\section{Bradford assay}

The Bradford assay using the Coomassie Blue reagent (Thermo Scientific, Chelmsford, MA, USA/Cat No 23200) was to detect proteins present in the bacterial culture medium which reflects protein leakage from bacterial cells. E. coli $\left(10^{4} \mathrm{cfu} / \mathrm{mL}\right) 1 \mathrm{~mL}$ was mixed with $100 \mu \mathrm{L}$ of lasergenerated $\mathrm{Ag}-\mathrm{TiO}_{2} \mathrm{NPs}$ in final concentration of 5, 10, 15 and $20 \mu \mathrm{g} / \mathrm{mL}$ and incubated overnight. Bacteria-Ag-TiO NP mix $1 \mathrm{~mL}$ was centrifuged at 12,000 rpm for 10 minutes, and $10 \mu \mathrm{L}$ supernatant from each sample were transferred to 96 -well plates. $250 \mu \mathrm{L}$ of Coomassie Blue reagent was then added to the well and the sample was mixed by shaking the plate for 30 minutes on a micro plate shaker and then further incubated at room temperature for 10 minutes. The absorbance of the sample was measured at $595 \mathrm{~nm}$ using the spectrophotometer (Omega). A standard curve of bovine serum albumin was included in each experiment to determine the protein concentration for each sample.

\section{DNA fragmentation}

Ag- $\mathrm{TiO}_{2}$ NPs or Ag NPs $1 \mathrm{~mL}$ at a concentration of $50 \mu \mathrm{g} / \mathrm{mL}$ was added to $5 \mathrm{~mL}$ of $E$. coli culture $\left(10^{4} \mathrm{cfu} / \mathrm{mL}\right)$ to give a final concentration of the NPs to be $10 \mu \mathrm{g} / \mathrm{mL}$. The bacterial cells were then cultured at $37^{\circ} \mathrm{C}$ with constant shacking at $225 \mathrm{rpm}$ for 3 hours. The bacterial cells were then pelleted by centrifugation at $8,000 \times g$ for 5 minutes, and DNA was extracted using the Genomic DNA kit (Cat No BioLine) according to the instructions by the manufacturer. DNA $200 \mathrm{ng}$ was loaded onto $1 \%$ agarose gel in Tris-acetate-EDTA (TAE) buffer in triplicate, and electrophoresis was carried out at constant voltage of $100 \mathrm{~V}$ for 1.5 hours.

\section{Cell culture and cytotoxicity assay}

Human lung adenocarcinoma cell line (A549, ATCC), human embryonic kidney cell line (HEK293, ATCC) ${ }^{27}$ and human liver cell line (HepG2, ATCC) were cultured in DMEM that were supplemented with $10 \%$ fetal bovine serum and $1 \%$ of penicillin/streptomycin. Primary human dermal fibroblast cells (HDFc, C0135C, Invitrogen, Inchinnan, UK) were cultured in DMEM/F12 media and primary human coronary artery endothelial cells (hCAECs, PromoCell, Heidelberg, Germany) were cultured in endothelial growth media with supplements (PromoCell) ${ }^{28}$ in $75 \mathrm{~cm}^{2}$ flasks in a $5 \% \mathrm{CO}_{2}$ incubator at $37^{\circ} \mathrm{C}$. MTT (MTT $[3,-4,5-$ dimethylthiazol-2-yl]-2,5-diphenyltetrazolium bromide) assay was used to determine the toxicity of the lasergenerated $\mathrm{Ag}-\mathrm{TiO}_{2} \mathrm{NPs}$ to the 5 types human cells above. The cells were first dissociated from the culture flasks using triple E (Sigma) and then seeded in 96-well plates in a density of 50 cells/well for HEK393, A549 and HDF cells, and 100 cells/well for the HEMC-1 and HepG2 cells. Twelve hours after cell seeding, the culture media was replaced by $100 \mu \mathrm{L}$ fresh media containing either 2.5 or $25 \mu \mathrm{g} / \mathrm{mL}$ laser-generated $\mathrm{Ag}-\mathrm{TiO}_{2} \mathrm{NPs}$ and incubated at $37^{\circ} \mathrm{C}$ in the $5 \% \mathrm{CO}_{2}$ incubator for 24,48 and 72 hours, respectively. A total of $10 \mu \mathrm{L}$ of $5 \mathrm{mg} / \mathrm{mL}$ MTT solution was added to each well and then $90 \mu \mathrm{L}$ of culture medium was added to the same well to give a final MTT concentration of $10 \%$ $(\mathrm{v} / \mathrm{v})$. After 4 hours, further culture at $37^{\circ} \mathrm{C}$ in the $5 \% \mathrm{CO}_{2}$ incubator, $100 \mu \mathrm{L}$ dimethyl sulfoxide (DMSO, equivalent to the original culture volume) was added, and the plate was incubated for 30 minutes at room temperature with shaking for color development. Finally, the plate was read using a plate reader at an absorbance wavelength of $600 \mathrm{~nm}$. The background absorbance was measured at wavelength of $690 \mathrm{~nm}$.

\section{Transmission electron microscopy (TEM)}

For the imaging of the human cells, laser-generated $\mathrm{Ag}-\mathrm{TiO}_{2} \mathrm{NPs}$ were added to the A549 cell culture to give a final concentration $20 \mu \mathrm{g} / \mathrm{mL}$ and then incubated at $37^{\circ} \mathrm{C}$ overnight. The cells were fixed with $4 \%$ formaldehyde containing 2.5\% glutaraldehyde in $0.1 \mathrm{M} 4$-(2-hydroxyethyl)-1piperazineethanesulfonic acid (Hepes) buffer ( $\mathrm{pH}$ 7.2) for 1 hour. Then the cells were treated with $1 \%$ osmium tetroxide and $1.5 \%$ potassium ferrocyanide in $0.1 \mathrm{M}$ cacodylate buffer ( $\mathrm{pH}$ 7.2) for 1 hour. The samples were dehydrated in ethanol series infiltrated with TAAB low viscosity resin and polymerized for 24 hours at $60^{\circ} \mathrm{C}$. Sections of $70 \mathrm{~nm}$ were prepared with Reichert Ultracut ultramicrotome and observed at FEI Tecnai 12 Biotwin microscope at $100 \mathrm{kV}$ accelerating voltage with Gatan Orius SC1000 CCD camera (Gatan, Inc., Pleasanton, CA, USA). 


\section{Statistical analysis}

Data in this study were presented as mean \pm SEM. Each experiment was performed in triplicate. Statistical significance was determined by one-way analysis of variance/ Student's $t$-test. $P$-values of $<0.05$ were considered significantly different.

\section{Results}

\section{Antibacterial effects of laser-generated $\mathrm{Ag}-\mathrm{TiO}_{2}$ compound NPs}

$\mathrm{Ag}-\mathrm{TiO}_{2} \mathrm{NPs}$ were generated by the picosecond laser. The average size of the $\mathrm{Ag}-\mathrm{TiO}_{2} \mathrm{NPs}$ was $47 \mathrm{~nm}$, ranging (10-200 nm, Figure 1A and B). UV-visible light absorption spectra for the $\mathrm{Ag}-\mathrm{TiO}_{2} \mathrm{NPs}$ and the $\mathrm{TiO}_{2} \mathrm{NPs}$ with various concentrations are presented in Figure $1 \mathrm{C}$ and D. The results show that compared with the pure $\mathrm{TiO}_{2}$ NPs (Figure 1D), the $\mathrm{Ag}-\mathrm{TiO}_{2} \mathrm{NPs}$ give rise to a band in the visible range that grows and shifts to longer wavelengths with increases in the NP concentration (Figure 1C). The spectral feature can be attributed to the plasmon-resonance absorption of the Ag NPs. The average zeta potential of $\mathrm{Ag}-\mathrm{TiO}_{2} \mathrm{NPs}$ at concentration $50 \mu \mathrm{g} / \mathrm{mL}$ and temperature $25^{\circ} \mathrm{C}$ was $-29.1 \pm 6.73$, suggesting reasonable stability of the colloidal dispersions.
Different concentrations of the laser-generated $\mathrm{Ag}-\mathrm{TiO}_{2}$ NPs were incubated with $E$. coli, $P$. aeruginosa and the MRSA at $37^{\circ} \mathrm{C}$. After 24 hours, clear ZOIs were observed for all bacterial strains (Figure 1E), suggesting significant bactericidal effects of the laser $\mathrm{Ag}-\mathrm{TiO}_{2} \mathrm{NPs}$ against both Gram-negative and Gram-positive bacteria, including the drug-resistant $S$. aureus strain. In contrast, laser-generated $\mathrm{TiO}_{2}$ NPs alone did not have any antibacterial effect at the same day light condition (Figure 1E). However, the ZOI for $\mathrm{Ag}-\mathrm{TiO}_{2} \mathrm{NPs}$ against $S$. aureus was significantly smaller compared with that of $E$. coli and $P$. aeruginosa (Figure 1E and F). The different effect is likely caused by the structural differences between Gram-positive and Gram-negative bacteria. ${ }^{29}$ Therefore, the bactericidal activity of laser-generated $\mathrm{Ag}-\mathrm{TiO}_{2}$ NPs depends not only on the concentration of NPs, but also the type of bacteria.

\section{Effect of ROS generation by laser- generated $\mathrm{Ag}-\mathrm{TiO}_{2}$ compound NPs}

$E$. coli was then used as model bacteria for the determination of $\mathrm{Ag}-\mathrm{TiO}_{2} \mathrm{NP}$-induced ROS generation. ROS indicator DCFH-DA used in the experiment measures a wide spectrum of different ROS species, including singlet oxygen,
A

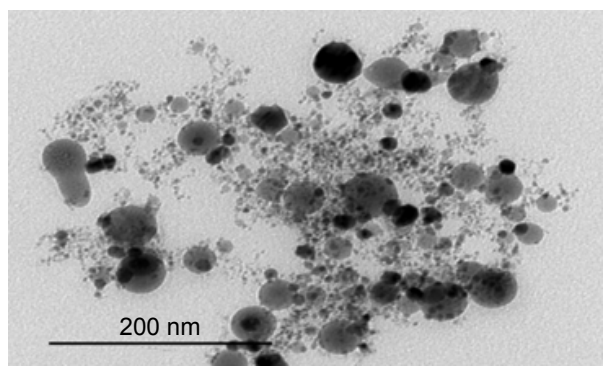

B

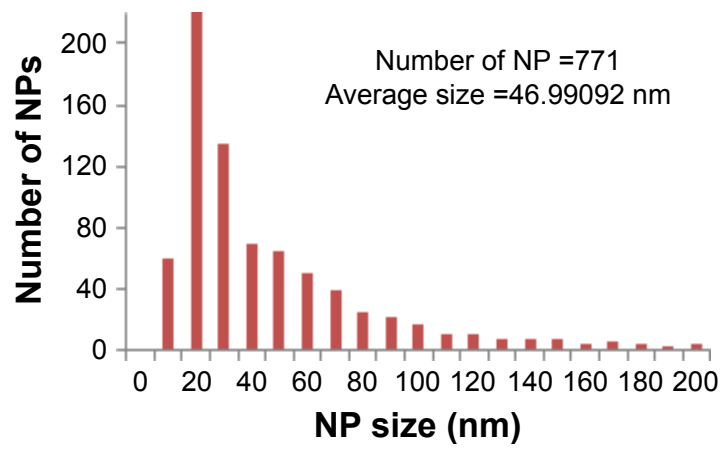

C

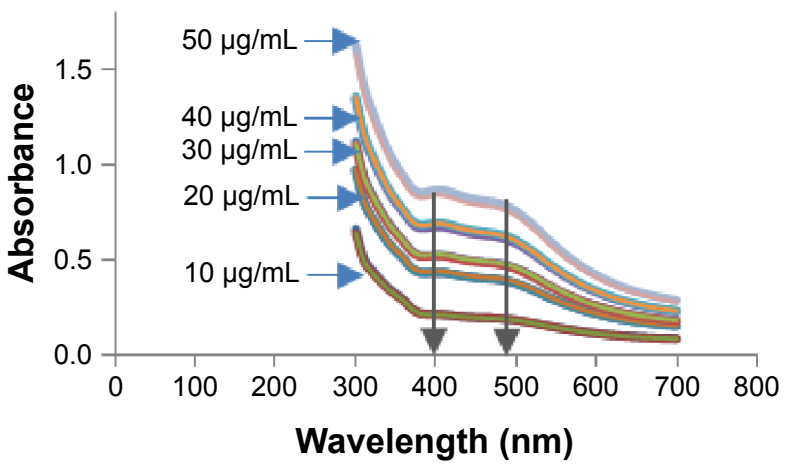

D

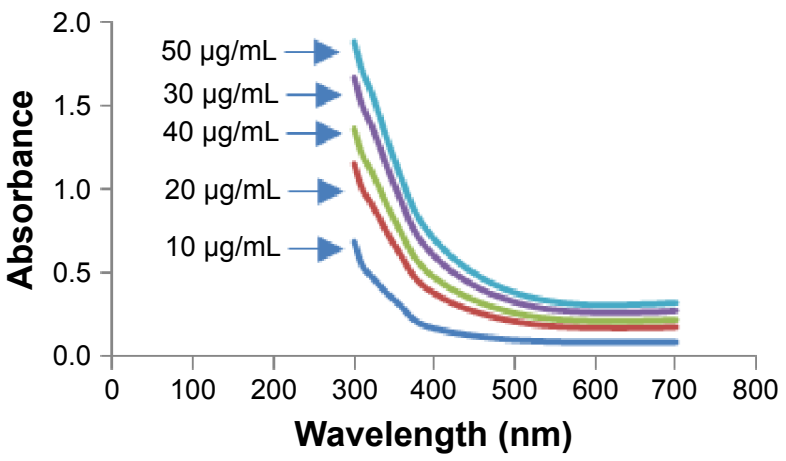

Figure I (Continued) 

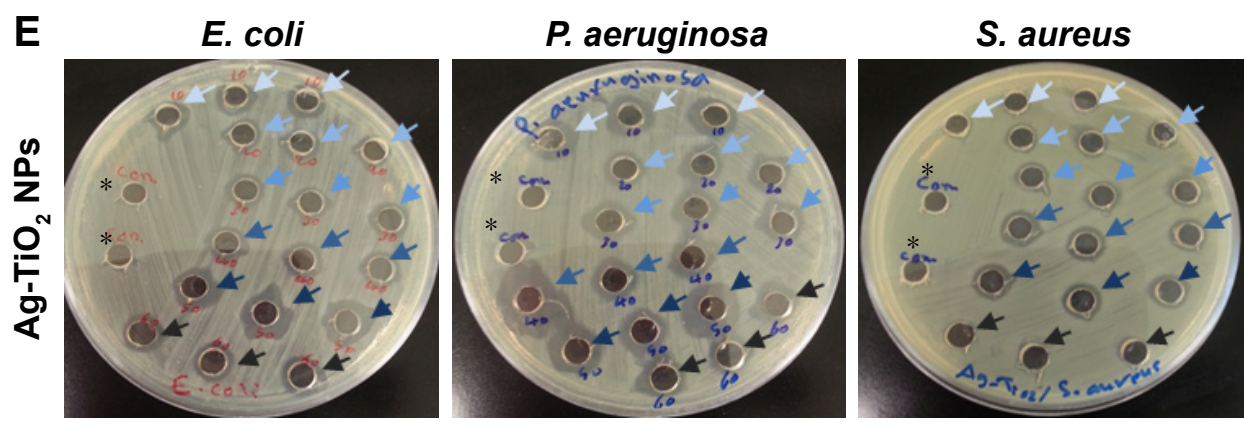

\section{Key:}

NP concentration

— $10 \mu \mathrm{g} / \mathrm{mL}$

< $20 \mu \mathrm{g} / \mathrm{mL}$
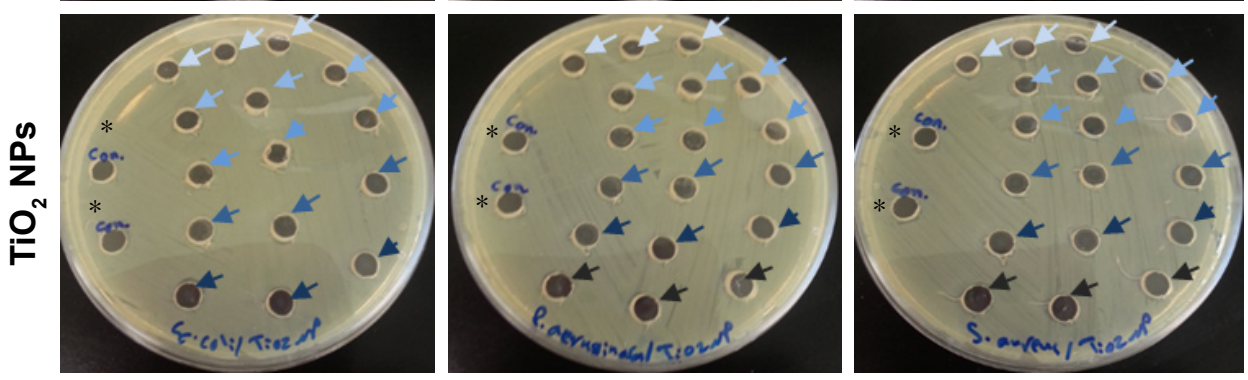

4. $30 \mu \mathrm{g} / \mathrm{mL}$

× $40 \mu \mathrm{g} / \mathrm{mL}$

$50 \mu \mathrm{g} / \mathrm{mL}$

- $60 \mu \mathrm{g} / \mathrm{mL}$

$\mathbf{F}$

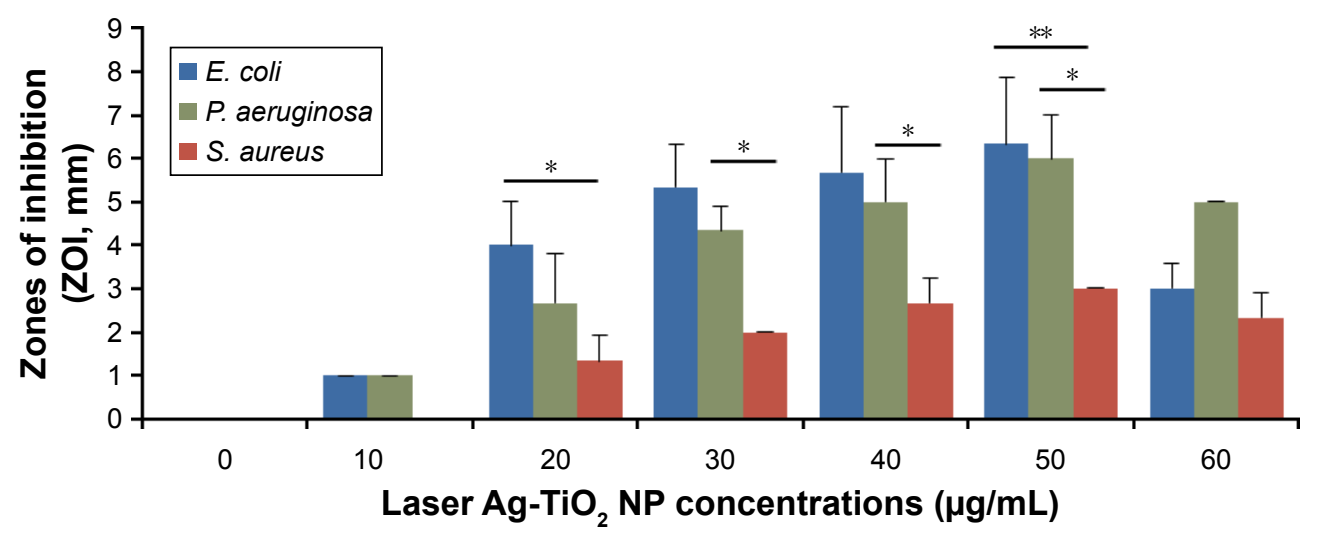

Figure I The antibacterial activity of laser-generated $\mathrm{Ag}-\mathrm{TiO}_{2} \mathrm{NPs}$ against Gram-positive and Gram-negative bacteria.

Notes: TEM image of laser Ag-TiO $\mathrm{NPs}_{2}(\mathbf{A})$. Size distribution of laser Ag-TiO 2 NPs (B). UV-vis spectrum of $\mathrm{Ag}-\mathrm{TiO} \mathrm{O}_{2} \mathrm{NPs}(\mathbf{C})$ and TiO $\mathrm{NPs}_{2}$ (D). A lawn of Escherichia coli, Staphylococcus aureus and Pseudomonas aeruginosa were made on Muller-Hinton agar plates and then $6 \mathrm{~mm}$ wells were created through the agar. Ag-TiO $\mathrm{NPs}_{50} \mu \mathrm{L}$ at different concentrations $(0,10,20,30,40,50$ and $60 \mu \mathrm{g} / \mathrm{mL})$ were added into each well in triplicate for each concentration, and the plates were incubated at $37^{\circ} \mathrm{C}$ for 24 hours. ZOI (E) was measured and the readings were corrected by the diameter of the well (F). Data are presented as mean \pm SE. Compared to $S$. aureus at the same concentration of $\mathrm{Ag} N \mathrm{NP}, * \mathrm{P} \leq 0.05, * * P \leq 0.0 \mathrm{I} ; \mathrm{n}=3$.

Abbreviations: NP, nanoparticle; TEM, transmission electron microscopy; ZOI, zone of inhibition.

super oxide, and hydrogen peroxide in addition to hydroxyl radicals. Result showed that the laser-generated $\mathrm{Ag}-\mathrm{TiO}_{2} \mathrm{NPs}$ at concentrations of 30 and $50 \mu \mathrm{g} / \mathrm{mL}$ have induced highly significant ROS generation compared with the non-NP treated control samples (Figure 2), suggesting the $\mathrm{Ag}-\mathrm{TiO}_{2} \mathrm{NPs}$ induced significant oxidative stress to the bacterial cells.

\section{Effect of laser-generated $\mathrm{Ag}-\mathrm{TiO}_{2}$ compound NPs on cellular GSH reductase level}

To further determine the molecular mechanisms that contribute to the bactericidal effect by the laser-generated Ag-TiO 2 NPs, levels of GSH in E. coli was measured after the bacteria were exposed to the laser-generated $\mathrm{Ag}-\mathrm{TiO}_{2}$
NPs $(15 \mu \mathrm{g} / \mathrm{mL})$ for 3 hours. Results showed that the GSH reductase level was significantly reduced compared with the non-NP treated control samples (Figure 3), suggesting cellular depletion of GSH, a critical antioxidant preventing cellular damages by oxidative stress, has happened in the laser $\mathrm{Ag}-\mathrm{TiO}_{2} \mathrm{NPs}$ treated E. coli.

\section{Effect of laser-generated $\mathrm{Ag}-\mathrm{TiO}_{2}$ compound NPs on LPO}

ROS accumulation usually leads to LPO, a key mechanism responsible for the increase in cell membrane permeability that contributes to cell death. LPO can be monitored by the generation of malonealdehyde (MAD). Figure 4 shows that the MAD level was significantly increased in the E. coli 


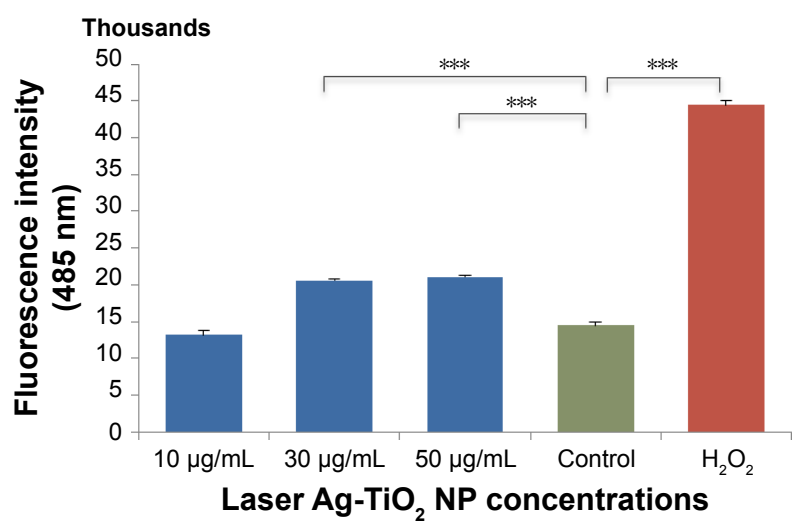

Figure 2 The effect of laser-generated $\mathrm{Ag}-\mathrm{TiO}_{2} \mathrm{NPs}$ on the production of ROS in Escherichia coli.

Notes: Different concentrations of laser $\mathrm{Ag}-\mathrm{TiO}_{2} \mathrm{NPs}(10,30$ and $50 \mu \mathrm{g} / \mathrm{mL})$ were cultured with $E$. coli for 5 hours in triplicate. The ROS levels were measured using the DCFH-DA kit and presented as the fluorescence intensity. Data are mean \pm SE. Compared to the NP-free control, $* * * P \leq 0.001, n=3$.

Abbreviations: DCFH-DA, dichlorofluorescein diacetate; NP, nanoparticle; ROS, reactive oxygen species.

after exposure to the laser $\mathrm{Ag}-\mathrm{TiO}_{2} \mathrm{NPs}$ at concentrations of 15 and $20 \mu \mathrm{g} / \mathrm{mL}$.

\section{Impact of laser-generated $\mathrm{Ag}-\mathrm{TiO}_{2}$ compound NPs on the integrity of bacterial cell membrane}

LDH release is considered to be a reliable indicator of cell membrane damages and increase in permeability. When E. coli were exposed to $10 \mu \mathrm{g} / \mathrm{mL}$ laser $\mathrm{Ag}-\mathrm{TiO}_{2} \mathrm{NPs}_{\text {for }}$ 24 hours, we detected significant LDH increase in the culture media (Figure 5A), suggesting cell membrane damage had occurred. The loss of cell integrity was also demonstrated using the protein leakage analysis. After treating E. coli bacterial culture with different concentrations of laser $\mathrm{Ag}-\mathrm{TiO}_{2}$

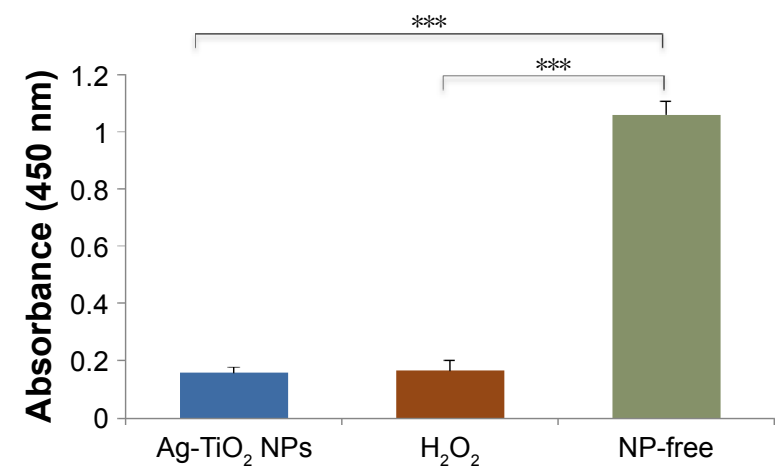

Figure 3 Changes of cellular glutathione reductase level in laser $\mathrm{Ag}-\mathrm{TiO}_{2} \mathrm{NP}$ treated Escherichia coli.

Notes: $E$. coli were treated with laser $\mathrm{Ag}-\mathrm{TiO}_{2} \mathrm{NPs}(15 \mu \mathrm{g} / \mathrm{mL})$ for 3 hours. The cellular glutathione reductase level was measured using the glutathione assay kit (Sigma). $\mathrm{H}_{2} \mathrm{O}_{2}(4 \mu \mathrm{g} / \mathrm{mL})$ treatment was used as a positive control, and the NP-free $\mathrm{dH}_{2} \mathrm{O}$ as a negative control. Data are presented as mean $\pm \mathrm{SE}$. Compared to the NP-free control, $* * * P \leq 0.001, \mathrm{n}=3$.

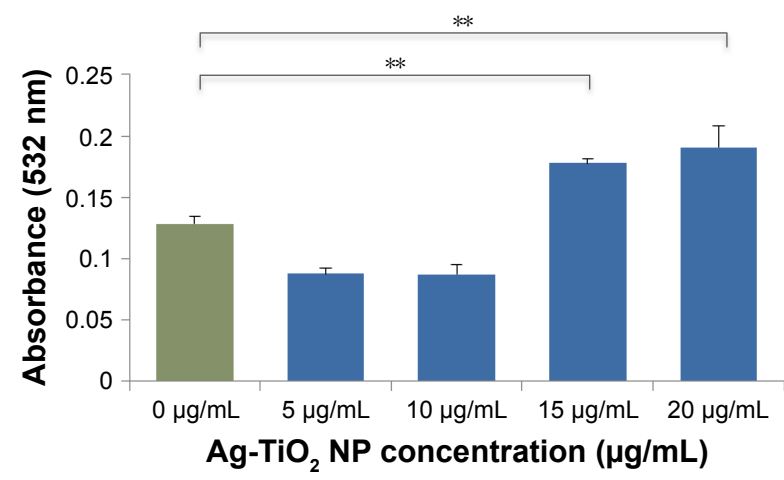

Figure 4 Lipid peroxidation in Escherichia coli by laser-generated $\mathrm{Ag}-\mathrm{TiO}_{2} \mathrm{NPs}$. Notes: Bacterial cells were treated with different concentrations of laser $\mathrm{Ag}-\mathrm{TiO}_{2}$ NPs for 3 hours. Cellular level of malondialdehyde was then measured using the MDA assay Kit (Sigma-Aldrich). Data are presented as mean \pm SE. Compared to the NP-free control, $* * P \leq 0.01, \mathrm{n}=3$.

Abbreviations: MDA, malondialdehyde; NP, nanoparticle.

NPs $(5,10,15$ and $20 \mu \mathrm{g} / \mathrm{mL})$ for 24 hours, a dose-dependent increase in the protein level was detected in the culture media as compared with the NP-free control samples (Figure 5B), indicating an increased cell membrane permeability.

\section{Effect of laser-generated $\mathrm{Ag}-\mathrm{TiO}_{2}$ compound NPs on bacterial DNA damage}

The effect of laser $\mathrm{Ag}_{-} \mathrm{TiO}_{2} \mathrm{NPs}_{\text {on }}$. coli DNA damage was tested and visualized using DNA agarose gel electrophoresis with the same amount of DNA (200 ng/lane) loaded into each lane. DNA samples treated with $\mathrm{Ag}-\mathrm{TiO}_{2} \mathrm{NPs}$ showed no significant change in the major genomic DNA band intensity compared with that of the non-NP treated controls (Figure 6), suggesting Ag- $\mathrm{TiO}_{2} \mathrm{NPs}$ did not induce significant DNA degradation. In contrast, DNA samples treated with the laser-generated Ag NPs had significant reduction of the major DNA band on agarose gel (Figure 6), suggesting significant DNA degradation. Results imply that, compared with Ag NPs, the laser-generated $\mathrm{Ag}-\mathrm{TiO}_{2}$ NPs are less likely causing bacterial DNA damage, and the antibacterial effect of Ag$\mathrm{TiO}_{2}$ composite NPs may rely more on the other molecular mechanisms as specified above.

\section{The toxicity of laser-generated $\mathrm{Ag}-\mathrm{TiO}_{2}$ compound NPs to human cells}

To evaluate the potential toxicity of the laser-generated Ag-TiO ${ }_{2}$ NPs to humans, 5 types of different human cells originated from the lung (A549 line), the blood vessel (hCAECs), the kidney (HEK293 line), the skin (HDFc cells) and the liver cells (HepG2 line) were tested. ${ }^{10}$ The cells were exposed to the laser $\mathrm{Ag}-\mathrm{TiO}_{2} \mathrm{NPs}$ for 3 different time 
A

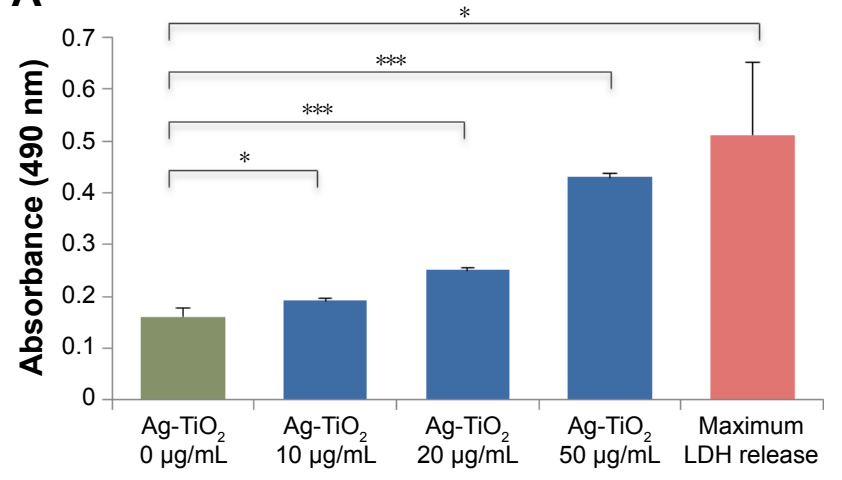

B

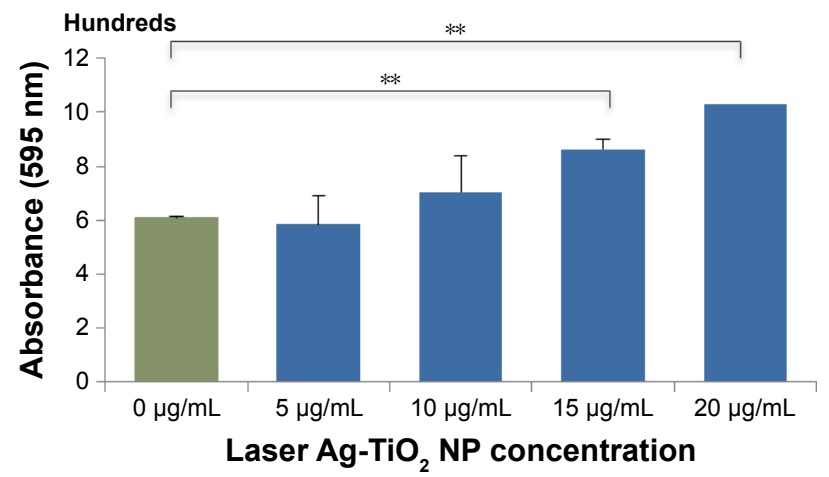

Figure 5 Effect of laser-generated $\mathrm{Ag}-\mathrm{TiO}_{2} \mathrm{NPs}$ on Escherichia coli membrane integrity.

Notes: $E$. coli were treated with different concentrations of laser $\mathrm{Ag}-\mathrm{TiO}_{2} \mathrm{NPs}$ for 24 hours. The culture media were subject for cell membrane integrity analysis using either the LDH assay kit (A) or the Coomassie reagent (B). A positive control was used for the LDH method by freezing and thawing the $E$. coli culture to physically break up the cell membrane integrity, named as maximum LDH release $(\mathbf{A})$. Data are mean $\pm \mathrm{SE}$. Compared to the NP-free control, $* P \leq 0.05, * * P \leq 0.0 \mathrm{I}$ and $* * * P \leq 0.00 \mathrm{I} ; \mathrm{n}=3$.

Abbreviations: LDH, lactate dehydrogenase; NP, nanoparticle.

periods $(24,48$ and 72 hours $)$ at both a low $(2.5 \mu \mathrm{g} / \mathrm{mL})$ and relatively high $(20 \mu \mathrm{g} / \mathrm{mL}) \mathrm{NP}$ concentrations followed by the MTT assay to measure the viable cells that inversely correlated with the number of dead cells. Slight but statistically significant growth delay was detected for hCAECs after 48 and 72 hours exposure to low concentrations of NPs, but no significant toxicity was observed when $20 \mu \mathrm{g} / \mathrm{mL}$ $\mathrm{Ag}-\mathrm{TiO}_{2} \mathrm{NPs}_{\mathrm{s}}$ were used (Figure 7A). Mild growth delay was also observed for A594 cell after 48 hours NP exposure, but disappeared after further culture up to 72 hours (Figure 7A). Similar mild growth delay was observed for $\mathrm{HDF} c$ cells at 48-hour time point when exposed to $20 \mu \mathrm{g} / \mathrm{mL} \mathrm{Ag-TiO}{ }_{2} \mathrm{NPs}$ but returned to normal at 72 hours (Figure 7A). There was no significant cytotoxicity observed for all 5 types of cells after

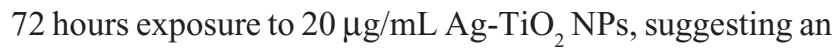
adaptive process had occurred in the cells over time and a low human cell cytotoxicity overall for the laser-generated
$\mathrm{Ag}-\mathrm{TiO}_{2} \mathrm{NPs}$ during the testing period. The reliability of the cytotoxicity assay was verified by using hydrogen peroxide $\left(\mathrm{H}_{2} \mathrm{O}_{2}\right)$ as a cytotoxicity inducer (positive control) on HDFc and $\mathrm{A} 594$ cells, which demonstrated that the toxicity of $\mathrm{H}_{2} \mathrm{O}_{2}$ to cells could be readily detected by the MTT assay employed in the study (Figure 7B).

To gain further insight into the impact of the laser-generated Ag-TiO 2 NPs to human cells, A594 cells were co-cultured with $\mathrm{Ag}-\mathrm{TiO}_{2} \mathrm{NPs}(20 \mu \mathrm{g} / \mathrm{mL})$ for 24 hours, and then imaged by TEM. We observed that the NPs were mainly located outside cell plasma membrane (Figure 8A). Intracellular NPs could be seen but they were rare (Figure 8B). Structure of mitochondrial and other cellular organelles were nicely preserved in the $\mathrm{Ag}-\mathrm{TiO}_{2} \mathrm{NP}$ treated cells (Figure 8A and $\mathrm{B}$ ). Results suggest that $\mathrm{Ag}-\mathrm{TiO}_{2} \mathrm{NPs}$ could be relatively non-toxic to mammalian cells. We did not observe any NPs in the cell nuclei, suggesting a low DNA toxicity to human cells.

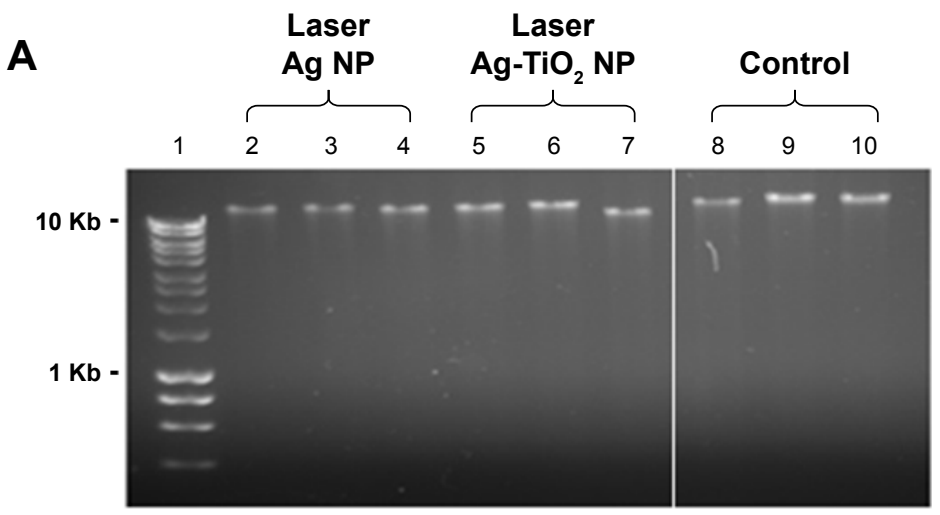

B

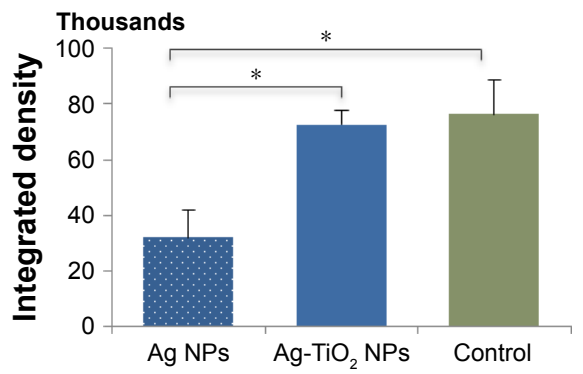

Figure 6 DNA degradation by laser $\mathrm{Ag}-\mathrm{TiO}_{2} \mathrm{NPs}$ in Escherichia coli.

Notes: $E$. coli were treated by laser-generated $\mathrm{Ag}-\mathrm{TiO}_{2} \mathrm{NPs}(10 \mu \mathrm{g} / \mathrm{mL})$ or laser Ag NPs $(10 \mu \mathrm{g} / \mathrm{mL})$ overnight. Genomic DNA were extracted and $200 \mathrm{ng}$ DNA were subjected to agarose gel electrophoresis (A). The intensity of the major DNA bands were quantified and shown in (B). Lane I, Hyperladder I (BioLine); Lane 5-7, laser $\mathrm{Ag}-\mathrm{TiO}_{2} \mathrm{NPs}$; Lane 2-4, laser Ag NPs; Lane 8-10, NP-free Control. Data were presented as mean \pm SE. Compared to the NP-free control, *P $\leq 0.05, \mathrm{n}=3$.

Abbreviation: NP, nanoparticle. 


\section{Discussion}

In this study, we demonstrated the antibacterial activities of a new type of $\mathrm{Ag}-\mathrm{TiO}_{2}$ compound NPs produced by picosecond laser and explored the molecular mechanisms underlying the bactericidal effects. The laser-generated $\mathrm{Ag}-\mathrm{TiO}_{2}$ compound NPs had wide spectrum of antibacterial activities against both Gram-negative (E. coli and $P$. aeruginosa) and Gram-positive (S. aureus) bacteria. To our knowledge,
A

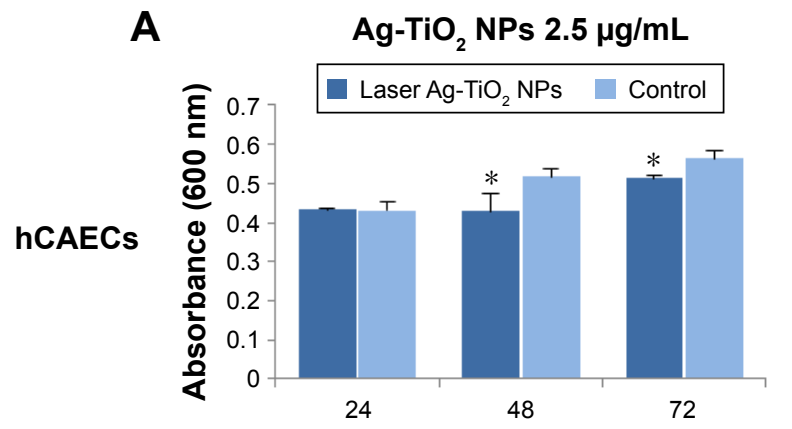

A594
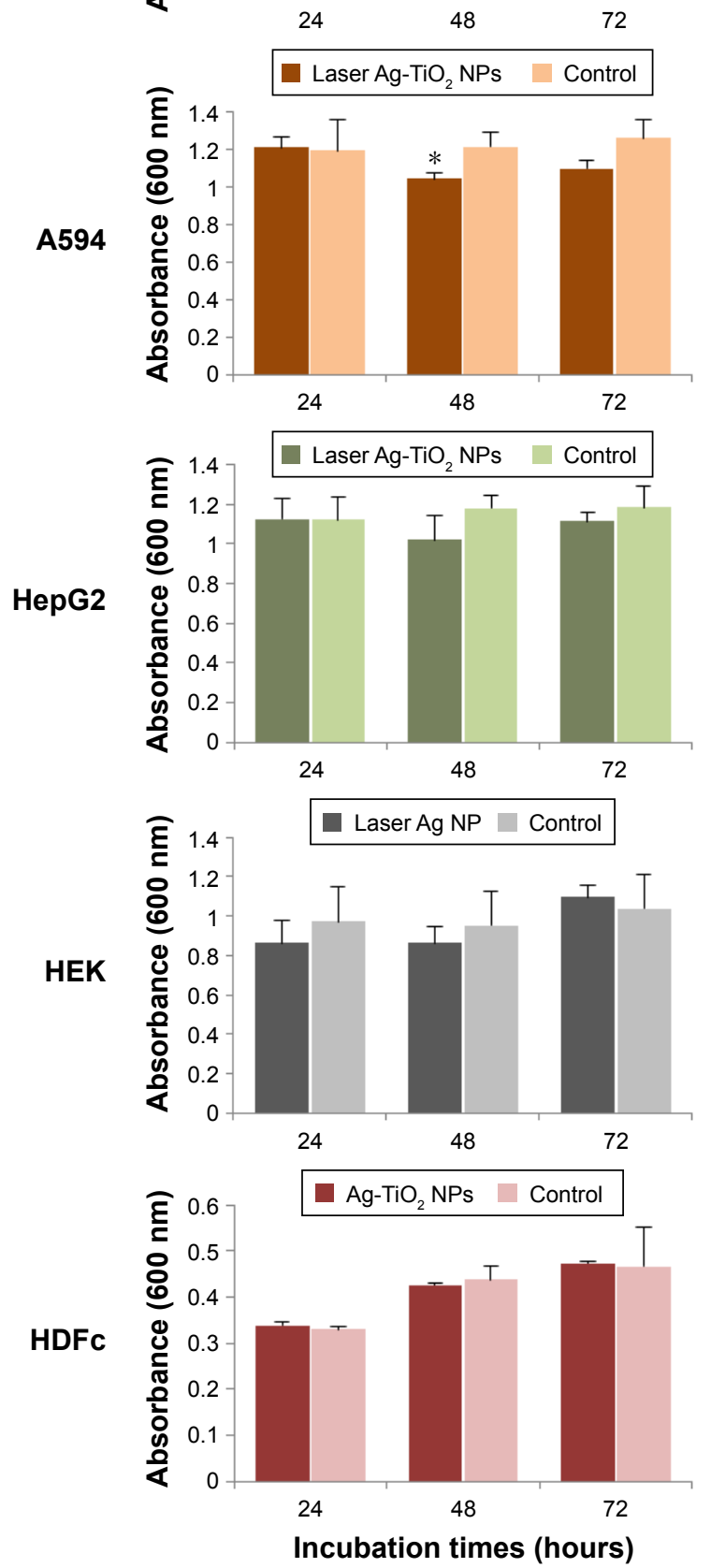

Ag- $\mathrm{TiO}_{2} \mathrm{NPs} 20 \mu \mathrm{g} / \mathrm{mL}$
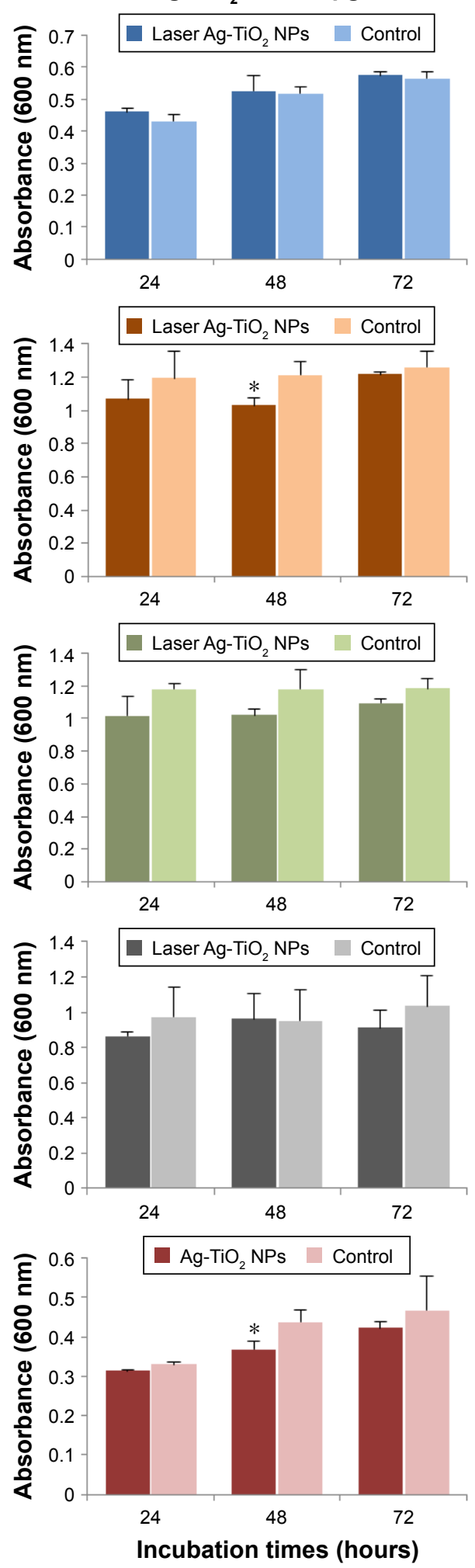

Figure 7 (Continued) 
B

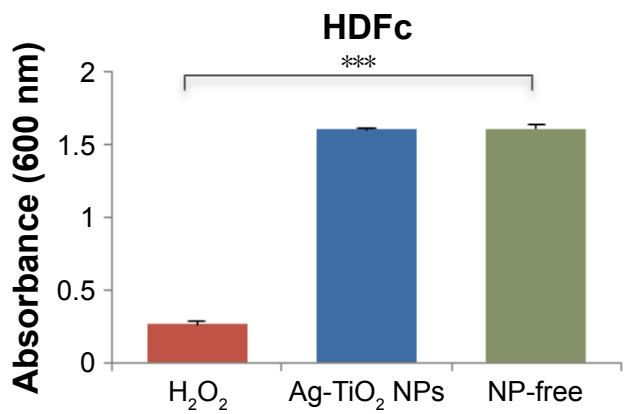

hCAECs

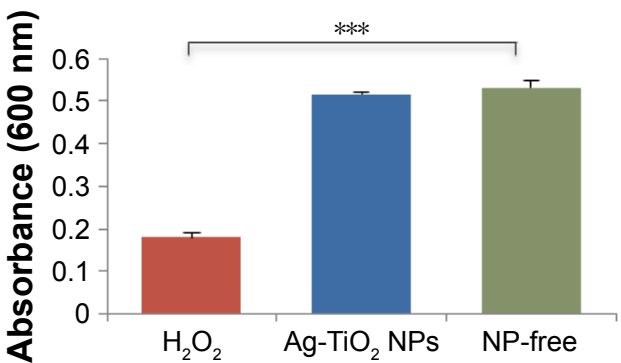

Figure 7 Cytotoxicity of laser-generated $\mathrm{Ag}-\mathrm{TiO}_{2} \mathrm{NPs}$ to human cells.

Notes: (A) The laser-generated Ag-TiO, NPs at two concentrations ( 2.5 and $20 \mu \mathrm{g} / \mathrm{mL}$ ) were incubated with 5 types of human cells or cell lines: A549 (lung), hCAECs (blood vessel), HEK293 (kidney), HDFc (skin) and the HepG2 (liver), for 24, 48 and 72 hours. Cytotoxicity was determined using MTT assay. (B) $\mathrm{H}_{2} \mathrm{O}_{2}$ was used as a positive control. HDFc and hCAECs were treated with either $40 \mu \mathrm{g} / \mathrm{mL} \mathrm{H} \mathrm{H}_{2}$ or with $20 \mu \mathrm{g} / \mathrm{mL} \mathrm{Ag-TiO}{ }_{2}$ NPs for 24 hours. Toxicity to the cells were measured using MTT assay. Data were presented as mean \pm SE. Compared to the NP-free control, $* P \leq 0.05$, $* * * P \leq 0.00 \mathrm{I}, \mathrm{n}=3$.

Abbreviations: hCAECs, human coronary artery endothelium cells; HDFc, human dermal fibroblast cells; NP, nanoparticle.

there has not been any report on the antibacterial effect of picosecond laser-generated $\mathrm{Ag}-\mathrm{TiO}_{2}$ compound NPs against both Gram-negative and Gram-positive bacterial strains. The $S$. aureus used in the study is a methicillin-resistant strain (MRSA). Our results therefore suggested an application potential for the laser-generated $\mathrm{Ag}-\mathrm{TiO}_{2} \mathrm{NPs}$ in medical healthcare for combating drug-resistant microbial infection or contaminations. The $\mathrm{Ag}-\mathrm{TiO}_{2} \mathrm{NPs}$ used in our study was directly produced by laser ablation of $\mathrm{Ag}-\mathrm{TiO}_{2}$ NPs alloy in pure water, which provides a green method for rapid production of $\mathrm{Ag}-\mathrm{TiO}_{2}$ composite NPs that could be readily used for health care applications without the need of eliminating contaminants that could be carried over from chemical reactions.

The antibacterial effects of the laser-generated $\mathrm{Ag}-\mathrm{TiO}_{2}$ NPs displayed significant dose dependency within the concentration range from 10 to $50 \mu \mathrm{g} / \mathrm{mL} \mathrm{Ag-TiO}{ }_{2} \mathrm{NPs}$ (Figure $1 \mathrm{E}$ and $\mathrm{F}$ ). At higher concentrations, there would be more NPs in direct contact and interacting with bacterial cell membrane, leading to better bactericidal effect. We also observed higher susceptibilities of $E$. coli and $P$. aeruginosa to the laser $\mathrm{Ag}-\mathrm{TiO}_{2} \mathrm{NPs}$ compared with that of $S$. aureus, (Figure 1E and F). This may be explained by the structural differences between Gram-positive and Gram-negative bacteria where the peptidoglycan layer is thicker in former that serves as a protective layer against chemicals, toxins, derivative enzymes and antibiotics. ${ }^{29}$

Being an antibacterial agent, $\mathrm{TiO}_{2}$ has several desirable properties, including stability, low toxicity and low cost. ${ }^{30}$ The antibacterial effect of $\mathrm{TiO}_{2}$ NPs attributes to the photocatalytic prosperity of $\mathrm{TiO}_{2}$, leading to ROS generation when illuminated by UV light. The requirement for the UV illumination has limited wider applications of $\mathrm{TiO}_{2}$ NPs, especially when live cells are involved. ${ }^{31}$ To overcome this limitation, efforts have been made to load noble metals such as $\mathrm{Ag} \mathrm{NPs}^{32}$ or gold $\mathrm{Au} \mathrm{NPs}{ }^{33}$ onto $\mathrm{TiO}_{2} \mathrm{NPs}$. Noble metals could enhance the photocatalytic activity of $\mathrm{TiO}_{2}$ by decreasing band gap of $\mathrm{TiO}_{2}$ to visible light wave
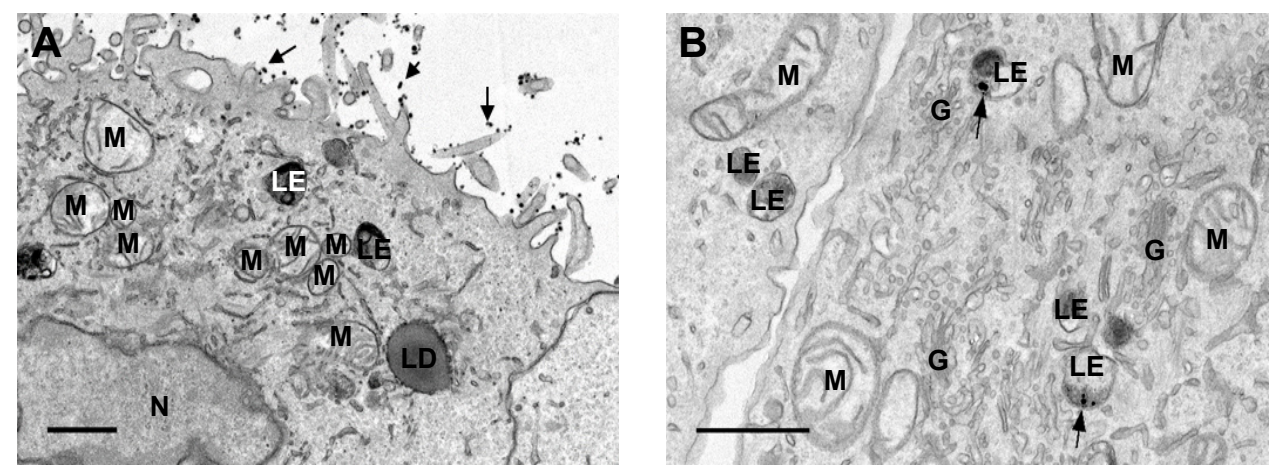

Figure 8 TEM images of human lung A549 cell line treated with laser-generated $\mathrm{Ag}-\mathrm{TiO}_{2} \mathrm{NPs}$.

Notes: TEM imaging was conducted on A549 cells that were treated with laser-generated Ag-TiO 2 NPs $(20 \mu g / m L)$ for 24 hours. Arrows in (A) indicate extracellular $\mathrm{Ag}-\mathrm{TiO}_{2} \mathrm{NPs}$. Arrows in (B) indicate intracellular $\mathrm{Ag}-\mathrm{TiO}_{2} \mathrm{NPs}$ within late endosomes. Scale bars indicate I $\mu \mathrm{m}$.

Abbreviations: G, golgi; LD, lipid droplet; LE, late endosomes; M, mitochondria; N, nucleus; NP, nanoparticle; TEM, transmission electron microscopy. 
range. ${ }^{34,35}$ This feature of $\mathrm{TiO}_{2}$ was indeed reflected by the laser-generated novel compound $\mathrm{Ag}-\mathrm{TiO}_{2} \mathrm{NPs}$ used in this study. The red shift of the absorption curve for the laser Ag- $\mathrm{TiO}_{2} \mathrm{NPs}_{\mathrm{N}}$ results in the reduction of the band gap energy and also the recombination rate, and hence, enhanced photocatalytic and antibacterial activities from the $\mathrm{TiO}_{2} \mathrm{NPs}$. The Ag component in the $\mathrm{Ag}-\mathrm{TiO}_{2} \mathrm{NPs}$ stores electrons, causing accumulation of so-called Valence-band hole on the $\mathrm{TiO}_{2} \mathrm{NPs}$, which could initiate oxidation reaction and ROS generation in the absence of light illumination. ${ }^{36} \mathrm{~A}$ study by Cao et al revealed an antibacterial effect of the $\mathrm{Ag}-\mathrm{TiO}_{2} \mathrm{NPs}$ in the dark, which was explained by the ability of Ag NPs to trap electrons, thus enhancing the attraction to bacterial cell membranes and leading to cell death. ${ }^{36}$

ROS is considered to be an important mechanism contributing to the antibacterial effect of $\mathrm{TiO}_{2}$. We have previously demonstrated an increased ROS generated in the bacterial culture by Ag NPs that were generated by picoseconds laser. ${ }^{10}$ In the current study, we measured ROS generation by the compound $\mathrm{Ag}-\mathrm{TiO}_{2} \mathrm{NPs}$ generated picosecond laser and confirmed that the new type of compound NPs possess the ability of producing ROS in bacteria as their individual composite does. ROS activates cellular antioxidant defense system in order to maintain equilibrium in the redox system. GSH reductase catalyzes the formation of GSH, which is a critical antioxidant to prevent cellular damages by oxidative stress. The excess accumulation of ROS would eventually deplete the cellular GSH pool, leading to insufficient antioxidant to overcome the accumulated ROS, resulting in cell damages. ${ }^{37} \mathrm{We}$ found that the laser-generated $\mathrm{Ag}-\mathrm{TiO}_{2} \mathrm{NPs}$ caused a highly significant reduction of GSH (Figure 3), suggesting the existence of GSH depletion, which contributes the antibacterial effects of the laser $\mathrm{Ag}-\mathrm{TiO}_{2} \mathrm{NPs}$.

ROS generated locally could result in damage of bacterial cell wall and membrane, and increase cell permeability, first to small molecules and then to large molecules such as $\beta$-D-galactosidase. ${ }^{38}$ Indeed, we detected significant amount of LDH enzyme and other proteins that leaked out of the E. coli after incubating with the $\mathrm{Ag}-\mathrm{TiO}_{2} \mathrm{NPs}$ (Figure 5A and B). Polyunsaturated phospholipids are the main components of the bacterial cell membrane. MDA is highly reactive byproduct of lipid oxidation that has the ability to react with proteins, forming protein-MDA complex, which is considered as a mutagenic compound. Our results showed that $E$. coli exposed to laser $\mathrm{Ag}-\mathrm{TiO}_{2} \mathrm{NPs}$ has increased the production of MDA (Figure 4), which is another mechanisms contributing to the disintegration of the bacteria cell membrane.
Accumulation of intracellular ROS could result in DNA damage. Interestingly, we did not observe significant DNA degradation in E. coli that co-cultured with the laser-generated $\mathrm{Ag}-\mathrm{TiO}_{2} \mathrm{NPs}$ (Figure 6A and $\mathrm{B}$ ). This is in contrast with our previous finding on DNA degradation induced by laser-generated Ag NPs. ${ }^{10}$ It is likely that mechanisms other than DNA damage could be more important for the bactericidal effects of laser-generated composite $\mathrm{Ag}-\mathrm{TiO}_{2} \mathrm{NPs}$, but additional studies are required to gain further insight.

Endothelial cells are important barriers in the blood vessels of human body that protect blood vessel injury and vascular function. Injury to endothelial cells lead to different pathophysiological disease such as atherosclerosis, myocardial infarction and thrombosis. ${ }^{39}$ Mild toxic effect of the laser $\mathrm{Ag}-\mathrm{TiO}_{2} \mathrm{NPs}$ was observed at 48 and 72 hours after the endothelial cells had received low concentration $(2.5 \mu \mathrm{g} / \mathrm{mL})$ of the $\mathrm{Ag}-\mathrm{TiO}_{2} \mathrm{NPs}$ challenge (Figure 7A). However, the lack of toxicity to endothelial cells at high concentration $(20 \mu \mathrm{g} / \mathrm{mL})$ could be due to the uptake saturation of the NPs and an adaptive response by the cells after 72 hours' co-culture. ${ }^{41}$

The most common route of human exposure to NPs is the respiratory tract, especially when the NPs size is small. After the NPs enter the human body, it will easily reach the alveolar where they either cause local damage to the lung epithelial cells or further travel to spleen, bone marrow and the heart via the blood or lymphatic circulation system for the smaller sized NPs. ${ }^{41}$ In this study, we observed that the growth of the A549 cell line that originated from the lung was sensitive to the laser $\mathrm{Ag}-\mathrm{TiO}_{2} \mathrm{NPs}$ treatment for 48 hours at both low $(2.5 \mu \mathrm{g} / \mathrm{mL})$ and high $(20 \mu \mathrm{g} / \mathrm{mL})$ concentrations of laser $\mathrm{Ag}-\mathrm{TiO}_{2} \mathrm{NPs}$ (Figure 7A). However, similar to what we have observed on the endothelial cells and skin fibroblast, the toxic effects were no longer obvious when the NPs were further incubated with the cells for up to 72 hours (Figure 7A), possibly through a similar adaptive mechanism as mentioned above for the endothelial. ${ }^{40}$

TEM images showed that the laser $\mathrm{Ag}-\mathrm{TiO}_{2} \mathrm{NPs}$ were only occasionally seen within the lysosome of A594 cells (Figure 8B). Vast majority of the laser Ag NPs is located outside the A594 cell membrane (Figure 8A). Previous finding by $\mathrm{Xu}$ et $\mathrm{al}^{42}$ demonstrated that NPs located in the nuclei or ribosomes of the cells were more toxic than those in the cytoplasm, even at low concentrations. In our study, we did not observe any laser $\mathrm{Ag}-\mathrm{TiO}_{2} \mathrm{NPs}$ that were in the nuclei. The lack of nuclear location of $\mathrm{Ag}-\mathrm{TiO}_{2} \mathrm{NPs}$, together with the nicely preserved structures of mitochondrial and 
other organelles, suggest that the toxic effect of the laser Ag- $\mathrm{TiO}_{2}$ NPs to human cells could be very mild.

One limitation of the current study is that, the cytotoxicity experiment was only conducted for up to 72 hours on the in vitro cell culture model. In vivo experiment on animal models will be useful to evaluate the long-term accumulation of the laser-generated $\mathrm{Ag}-\mathrm{TiO}_{2} \mathrm{NP}$. Further studies could also separate NPs into different sizes using fractionation techniques to more precisely determine their correlation of the $\mathrm{Ag}-\mathrm{TiO}_{2}$ NPs size with the biological function and toxicity.

\section{Conclusion}

The picoseconds laser-generated $\mathrm{Ag}-\mathrm{TiO}_{2}$ compound NPs demonstrated strong antibacterial activity against 3 types of bacteria (E. coli, P. aeruginosa, S. aureus), including the methicillin-resistant strain, MRSA, under standard laboratory daylight condition. The mechanisms contributing to the antibacterial properties were found to be ROS generation, GSH reduction, LPO, cell membrane damages and protein leakage. Up to 3 days co-culture, the laser-generated Ag$\mathrm{TiO}_{2}$ NPs showed low toxicity to the human cells originated from the lung, kidney, liver, skin and blood vessel cells. The laser-generated $\mathrm{Ag}-\mathrm{TiO}_{2}$ NPs mostly attached themselves to the human cell plasma membranes and few penetrated into the cells and none was found in the cell nucleus. The antimicrobial properties of the new type of picoseconds laser-generated $\mathrm{Ag}-\mathrm{TiO}_{2}$ compound NPs could have potential biomedical applications.

\section{Acknowledgments}

The authors would like to thank Mr Abubaker Hamad from the School of Mechanical, Aerospace and Civil Engineering, the University of Manchester for his assistance in the generation of Ag NPs using laser ablation technology.

\section{Disclosure}

The authors report no conflicts of interest in this work.

\section{References}

1. Rai M, Yadav A, Gade A. Silver nanoparticles as a new generation of antimicrobials. Biotechnol Adv. 2009;27(1):76-83.

2. Avalos A, Haza AI, Mateo D, Morales P. Interactions of manufactured silver nanoparticles of different sizes with normal human dermal fibroblasts. Intl Wound J. 2016;13(1):101-109.

3. Aditya NP, Vathsala PG, Vieira V, Murthy RS, Souto EB. Advances in nanomedicines for malaria treatment. Adv Colloid Interface Sci. 2013; 201-202:1-17.

4. Juan L, Zhimin Z, Anchun M, Lei L, Jingchao Z. Deposition of silver nanoparticles on titanium surface for antibacterial effect. Int J Nanomedicine. 2010;5:261-267.
5. Yu B, Leung KM, Guo Q, Lau WM, Yang J. Synthesis of Ag-TiO2 composite nano thin film for antimicrobial application. Nanotechnology. 2011;22(11):115603.

6. Gupta K, Singh R, Pandey A, Pandey A. Photocatalytic antibacterial performance of TiO2 and Ag-doped TiO2 against $S$. aureus, $P$. aeruginosa and E. coli. Beilstein J Nanotechnol. 2013;4(1):345-351.

7. Ramesh P, Muthukkumarasamy S, Dhanabalan K, Sadhasivam T, Gurunathan K. Synthesis and characterization of Ag and TiO2 nanoparticles and their anti-microbial activities. Dig JNanomater Biostruct. 2012;7(4):1501-1508.

8. Arabatzis I, Stergiopoulos T, Bernard M, Labou D, Neophytides S, Falaras P. Silver-modified titanium dioxide thin films for efficient photodegradation of methyl orange. Appl Catal B Environ. 2003;42(2): 187-201.

9. Ashkarran A. Antibacterial properties of silver-doped $\mathrm{TiO} 2$ nanoparticles under solar simulated light. J Theoret Appl Phys. 2011;4(4): $1-8$.

10. Korshed P, Li L, Liu Z, Wang T. The molecular mechanisms of the antibacterial effect of picosecond laser generated silver nanoparticles and their toxicity to human cells. PLoS One. 2016;11(8):e0160078.

11. Hajipour MJ, Fromm KM, Ashkarran AA, et al. Antibacterial properties of nanoparticles. Trends Biotechnol. 2012;30(10):499-511.

12. Mills A, Le Hunte S. An overview of semiconductor photocatalysis. J Photochem Photobiol. 1997;108(1):1-35.

13. Shukla RK, Sharma V, Pandey AK, Singh S, Sultana S, Dhawan A. ROS-mediated genotoxicity induced by titanium dioxide nanoparticles in human epidermal cells. Toxicol In Vitro. 2011;25(1):231-241.

14. Biello D [webpage on the Internet]. Do nanoparticles and sunscreen mix? Scient Am. Available from: http://www.scientificamerican.com/ article.cfm?id=do-nanoparticles-and-sunscreen-mix. 2007. Accessed September 1, 2016.

15. Drake PL, Hazelwood KJ. Exposure-related health effects of silver and silver compounds: a review. Ann Occup Hyg. 2005;49(7):575-585.

16. Bartlomiejczyk T, Lankoff A, Kruszewski M, Szumiel I. Silver nanoparticles allies or adversaries? Ann Agric Environ Med. 2013;20(1):48-54.

17. Liu W, Wu Y, Wang C, et al. Impact of silver nanoparticles on human cells: effect of particle size. Nanotoxicology. 2010;4(3):319-330.

18. Liu X, Liu Z, Lu J, Wu X, Chu W. Silver sulfide nanoparticles sensitized titanium dioxide nanotube arrays synthesized by in situ sulfurization for photocatalytic hydrogen production. J Colloid Interface Sci. 2014;413:17-23.

19. Jhuang YY, Cheng WT. Fabrication and characterization of silver/ titanium dioxide composite nanoparticles in ethylene glycol with alkaline solution through sonochemical process. Ultrason Sonochem. 2016;28:327-333.

20. Massa MA, Covarrubias C, Bittner M, et al. Synthesis of new antibacterial composite coating for titanium based on highly ordered nanoporous silica and silver nanoparticles. Mater Sci Eng C Master Biol Appl. 2014; 45:146-153.

21. Pan X, Medina-Ramirez I, Mernaugh R, Liu J. Nanocharacterization and bactericidal performance of silver modified titania photocatalyst. Colloids Surf B Biointerfaces. 2010;77(1):82-89.

22. Hamad A, Li L, Liu Z, Zhong XL, Liu H, Wang T. Generation of silver titania nanoparticles from an Ag-Ti alloy via picosecond laser ablation and their antibacterial activities. RSC Advances. 2015;5(89): 72981-72994.

23. Hamad A, Li L, Liu Z. A comparison of the characteristics of nanosecond, picosecond and femtosecond lasers generated Ag, TiO2 and Au nanoparticles in deionised water. Appl Phys A. 2015;120(4):1247-1260.

24. Kavita K, Singh VK, Jha B. 24-Branched $\Delta 5$ sterols from laurencia papillosa red seaweed with antibacterial activity against human pathogenic bacteria. Microbiol Res. 2014;169(4):301-306.

25. Chhibber S, Kaur T, Kaur S. Co-therapy using lytic bacteriophage and linezolid: effective treatment in eliminating methicillin resistant Staphylococcus aureus (MRSA) from diabetic foot infections. PLoS One. 2013;8(2):e56022. 
26. $\mathrm{Xu} \mathrm{H}, \mathrm{Qu} \mathrm{F}, \mathrm{Xu} \mathrm{H}$, et al. Role of reactive oxygen species in the antibacterial mechanism of silver nanoparticles on Escherichia coli O157: H7. Biometals. 2012;25(1):45-53.

27. Wang T, Holt CM, Xu C, et al. Notch3 activation modulates cell growth behaviour and cross-talk to Wnt/TCF signalling pathway. Cell Signal. 2007;19(12):2458-2467.

28. Elliott GC, Gurtu R, McCollum C, Newman WG, Wang T. Foramen ovale closure is a process of endothelial-to-mesenchymal transition leading to fibrosis. PLoS One. 2014;9(9):e107175.

29. Kim SH, Lee HS, Ryu DS, Choi SJ, Lee DS. Antibacterial activity of silver-nanoparticles against Staphylococcus aureus and Escherichia coli. Korean J Microbiol Biotechnol. 2011;39(1):77-85.

30. Dhanalekshmi K, Meena K, Ramesh I. Synthesis and characterization of Ag@ TiO2 core-shell nanoparticles and study of its antibacterial activity. Int $J$ Nanotechnol. 2013;3(5):5-14.

31. Pelgrift RY, Friedman AJ. Nanotechnology as a therapeutic tool to combat microbial resistance. Adv Drug Deliv Rev. 2013;65(13-14): 1803-1815.

32. Yang XH, Fu HT, Wong K, Jiang XC, Yu AB. Hybrid Ag@ TiO2 core-shell nanostructures with highly enhanced photocatalytic performance. Nanotechnology. 2013;24(41):415601.

33. Tamiolakis I, Fountoulaki S, Vordos N, Lykakis IN, Armatas GS. Mesoporous $\mathrm{Au}-\mathrm{TiO} 2$ nanoparticle assemblies as efficient catalysts for the chemoselective reduction of nitro compounds. J Mater Chem A. 2013; 1(45):14311-14319.

34. Sripriya J, Anandhakumar S, Achiraman S, Antony JJ, Siva D, Raichur AM. Laser receptive polyelectrolyte thin films doped with biosynthesized silver nanoparticles for antibacterial coatings and drug delivery applications. Int J Pharm. 2013;457(1):206-213.
35. Fujishima A, Zhang X. Titanium dioxide photocatalysis: present situation and future approaches. C R Chim. 2006;9(5):750-760.

36. Cao H, Qiao Y, Liu X, et al. Electron storage mediated dark antibacterial action of bound silver nanoparticles: smaller is not always better. Acta Biomater. 2013;9(2):5100-5110.

37. Feinendegen LE. Reactive oxygen species in cell responses to toxic agents. Hum Exp Toxicol. 2002;21(2):85-90.

38. Huang Z, Maness P, Blake D, Wolfrum E, Smolinski S, Jacoby W. Bactericidal mode of titanium dioxide photocatalysis. J Photochem photobiol A. 2000;130(2-3):163-170.

39. Shi J, Sun X, Lin Y, et al. Endothelial cell injury and dysfunction induced by silver nanoparticles through oxidative stress via IKK/NF- $\kappa \mathrm{B}$ pathways. Biomaterials. 2014;35(24):6657-6666.

40. Lankoff A, Sandberg WJ, Wegierek-Ciuk A, et al. The effect of agglomeration state of silver and titanium dioxide nanoparticles on cellular response of HepG2, A549 and THP-1 cells. Toxicol Lett. 2012; 208(3):197-213.

41. Jennifer M, Maciej W. Nanoparticle technology as a double-edged sword: cytotoxic, genotoxic and epigenetic effects on living cells. J Biomater Nanobiotechnol. 2013;4(1):53-63.

42. Xu P, Van Kirk EA, Zhan Y, Murdoch WJ, Radosz M, Shen Y. Targeted charge-reversal nanoparticles for nuclear drug delivery. Angew Chem Int Ed Engl. 2007;46(26):4999-5002.
International Journal of Nanomedicine

\section{Publish your work in this journal}

The International Journal of Nanomedicine is an international, peerreviewed journal focusing on the application of nanotechnology in diagnostics, therapeutics, and drug delivery systems throughout the biomedical field. This journal is indexed on PubMed Central,

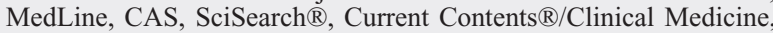

\section{Dovepress}

Journal Citation Reports/Science Edition, EMBase, Scopus and the Elsevier Bibliographic databases. The manuscript management system is completely online and includes a very quick and fair peer-review system, which is all easy to use. Visit http://www.dovepress.com/ testimonials.php to read real quotes from published authors. 